\title{
Pengaruh Kinerja Keuangan dan Karakteristik Perusahaan terhadap Pengungkapan Lingkungan di Perusahaan yang terdaftar di Singapore Exchange
}

\author{
Indah Fajarini Sri Wahyuningrum, Nilam Putri, dan Retnonigrum Hidayah
}

Jurusan Akuntansi, Fakultas Ekonomi, Universitas Negeri Semarang; e-mail: i.fajarini@mail.unnes.ac.id

\begin{abstract}
ABSTRAK
Pengungkapan lingkungan merupakan salah satu bentuk tanggung jawab perusahaan terhadap lingkungan di sekitarnya. Pengungkapan lingkungan diharapkan juga dapat menarik para stakeholder untuk berinvestasi dan memberikan keuntungan pada perusahaan. Meskipun otoritas di beberapa negara masih tidak mewajibkan perusahaan untuk mengeluarkan pengungkapan lingkungan, pengungkapan lingkungan menjadi sesuatu yang penting karena mencakup seluruh aktivitas perusahaan dan dampaknya terhadap lingkungan. Namun, banyak perusahaan yang lebih berfokus pada kinerja perusahaan dan belum menyajikan pengungkapan lingkungan dalam laporan tahunannya. Oleh sebab itu, penelitian ini dilakukan untuk mengidentifikasi pengaruh antara kinerja keuangan dan karakteristik perusahaan terhadap pengungkapan lingkungan perusahaan. Variabel dependen dalam penelitian ini adalah pengungkapan lingkungan yang diukur dengan checklist items sesuai dengan Global Reporting Initiatives (GRI) Standard 2016. Terdapat empat variabel independen dalam penelitian ini yaitu: profitabilitas (Return on Equity - ROE), leverage, ukuran perusahaan dan tipe industri. Penelitian ini menggunakan data yang diperoleh dari laporan tahunan (annual report), laporan berkelanjutan (sustainability report) milik perusahaan yang terdaftar di Singapore Exchange (SGX) tahun 2018. Terdapat 61 perusahaan sebagai sampel dan diambil sesuai dengan metode purposive sampling. Penelitian ini menggunakan teknik analisis linear berganda sebagai metode analisis untuk menguji pengaruh dari variable-variabel independen terhadap pengungkapan lingkungan. Hasil penelitian menunjukkan bahwa ukuran perusahaan terbukti berpengaruh positif signifikan terhadap pengungkapan lingkungan. Hal ini memperkuat bukti bahwa semakin besar ukuran perusahaan, kesadaran perusahaan lebih tinggi untuk melakukan pengungkapan lingkungan. Sebaliknya tiga variabel lain yaitu profitabilitas, leverage, dan tipe industri terbukti tidak berpengaruh signifikan terhadap pengungkapan lingkungan perusahaan yang terdaftar di SGX.
\end{abstract}

Kata kunci: ukuran perusahaan, profitabilitas, leverage, tipe industri, pengungkapan lingkungan

\begin{abstract}
Environmental disclosure is a part of corporate responsibility towards surrounding environment. Environmental disclosure is also expected to attract stakeholders to invest to the company. Eventhough authorities in some countries still do not oblige companies to issue environmental disclosures, environmental disclosure is important because it includes all company activities and their impact on the environment. However, many companies do not have awareness to present these environmental disclosures in their annual reports. Therefore, this study aims to explore the effect of financial company performance and company characteristics on the environmental disclosure. The dependent variable in this study is environmental disclosure which is measured by a check list item according to the Global Reporting Initiative (GRI) Standards 2016. There are four independent variables namely company size, profitability, leverage, and type of industry. This study used data which was obtained from annual reports and sustainability reports of companies which were listed on Singapore Exchange (SGX) in 2018. There were 61 companies as the sample that chosen based on purposive sampling method. This study used multiple linear regression analysis to determine the effect of independent variables on environmental disclosure. The results indicate that company size has a significant effects on environmental disclosure. It can be said that the larger the company size, the higher the company's awareness for environmental disclosure. Meanwhile, profitability, leverage and type of industry do not have a positive significant to environmental disclosure of companies listed in SGX.
\end{abstract}

Keywords: company size, profitability, leverage, type of industry, environmental disclosure

Citation: Wahyuningrum, I.F.S., Putri, N., dan Hidayah, R. (2020). Pengaruh Kinerja Keuangan dan Karakteristik Perusahaan terhadap Pengungkapan Lingkungan di Perusahaan yang terdaftar di Singapore Exchange. Jurnal Ilmu Lingkungan, 18(2), 417-423, doi:10.14710/jil.18.2.417-423

\section{Pendahuluan}

Masalah lingkungan masih menjadi tantangan di berbagai negara dan selalu menarik perhatian masyarakat. Hal ini memicu peningkatan kesadaran masyarakat untuk lebih mengetahui peran perusahaan di dalam masyarakat terutama yang terkait dengan masalah lingkungan (D'Amico, Coluccia, Fontana, \& Solimene, 2016). Sejumlah perusahaan yang telah berkontribusi pada perkembangan dunia perekonomian dan kemajuan 
Wahyuningrum, I.F.S., Putri, N., dan Hidayah, R. (2020). Pengaruh Kinerja Keuangan dan Karakteristik Perusahaan terhadap Pengungkapan Lingkungan di Perusahaan yang terdaftar di Singapore Exchange. Jurnal IImu Lingkungan, 18(2), 417-423, doi:10.14710/jil.18.2.417-423

teknologi, terkadang masih menuai kritik dari masyarakat terkait dengan permasalahan yang berhubungan dengan lingkungan sekitarnya. Permasalahan terkait polusi dan limbah yang dihasilkan oleh perusahaan yang tidak dikelola dan tidak terkomunikasikan dengan baik memicu penolakan masyarakat terhadap keberadaaan perusahaan di sekitar mereka (Liu \& Zhang, 2017). Munculnya beberapa permasalahan dengan masyarakat terkait pengelolaan lingkungan ini membuat perusahaan lebih peduli terhadap lingkungan. Salah satu bentuk kepedulian perusahaan terhadap lingkungan dan masyarakat terwujudkan dalam bentuk tanggung jawab social perusahaan atau Corporate Social Responsibility (CSR) (Chen, Hung, \& Wang, 2018). Menurut Roberts (1992), CSR dapat didefinisikan sebagai kebijakan dari perusahaan atau organisasi yang mengidentifikasi keprihatinan dengan isu-isu yang berkaitan dengan masyarakat sekitar.

Di sisi lain, meningkatnya minat dalam pengungkapan informasi lingkungan atau praktik pengungkapan lingkungan (environmental disclosure) sudah menjadi salah satu strategi untuk mencapai kesuksesan perusahaan (Plumlee, Brown, Hayes, \& Marshall, 2015). Adanya berbagai permasalahan yang timbul terkait lingkungan telah membuat perusahaan untuk tidak hanya menjalankan bisnisnya hanya demi mendapatkan profit semata namun juga memiliki kewajiban tanggung jawab sosial kepada masyarakat diluar perusahaan dan lingkungan (Khlif, Guidara, \& Souissi, 2015). Hal ini sejalan dengan pedoman pengungkapan lingkungan yang diterbitkan oleh Global Reporting Initiative (GRI) yang menjelaskan bahwa perusahaan harus memberikan kontribusi yang nyata terhadap pemecahan permasalahan terhadap risiko keberlanjutan didalam hubungan perekonomian, sosial, dan lingkungan.

Sampai saat ini, masih banyak peraturan di beberapa negara yang tidak mewajibkan perusahaan untuk melaporkan pengungkapan lingkungan secara berkala dalam annual report maupun sustainability report (Jackson, Bartosch, Avetisyan, Kinderman, \& Knudsen, 2020). Pengungkapan lingkungan sendiri merupakan pelaporan oleh perusahaan yang menjelaskan dampak kegiatan perusahaan terhadap lingkungan. Kegiatan perusahaan ini meliputi pengelolaan limbah, daur ulang, pengelolaan karbon, emisi, dan polusi. Seiring dengan meningkatnya kebutuhan terhadap informasi pengungkapan keberlanjutan bagi pemangku kepentingan perusahaan, popularitas pengungkapan lingkungan ini juga akan meningkat. Alotaibi and Hussainey (2016) menegaskan bahwa saat ini pengungkapan keberlanjutan telah menjadi pilar utama dari kegiatan bisnis perusahaan seiring dengan meningkatnya kesadaran dari pemangku kepentingan.

Hal ini juga mendorong perusahaan-perusahaan di Singapura lebih sadar untuk memasukkan CSR sebagai salah satu komponen CSR dalam laporan tahunan mereka. Kepedulian dan kesadaran perusahan-perusahaan ini diawali dengan diterbitkannya pedoman pelaporan keberlanjutan pada Juni 2011 oleh Singapore Exchange (SGX). Salah satu metode pemeringkatan untuk mengukur dan melakukan perbandingan kinerja lingkungan atas kebijakan suatu negara adalah Environmental Performance Index (EPI) yang berdiri tahun 2002. Berdasarkan EPI tahun 2016, Singapura berada di rangking ke-14 dengan total skor sebesar 87,04. Sebaliknya, hasil EPI Singapura pada tahun 2018 menunjukkan terjadinya penurunan. Peringkat Singapura yang semula berada di peringkat ke-14v turun menjadi peringkat ke-49 dengan skor 64,23.

Selama lebih dari satu dekade ini banyak penelitian yang menguji karakteristik perusahaan terhadap pengungkapan lingkungan dengan hasil yang inkonsisten. Penelitian yang dilakukan oleh Burgwal and Vieira (2014), Khalid, Kouhy, and Hassan (2017), dan Wahyuningrum and Budihardjo (2018) menunjukkan adanya pengaruh positif signifikan antara ukuran perusahaan terhadap pengungkapan lingkungan. Sebaliknya, ukuran perusahaan terbukti tidak berpengaruh terhadap pengungkapan lingkungan di Nigeria (Dibia \& Onwuchekwa, 2015). Gatimbu and Wabwire (2016) menguji pengaruh kinerja keuangan terhadap pengungkapan lingkungan perusahaan yang terdaftar di Bursa Efek Nairobi, Kenya. Hasil penelitian tersebut membuktikan adanya pengaruh secara positif kinerja keuangan terhadap pengungkapan lingkungan. Sejalan dengan penelitian terdahulu, Mathuva and Kiweu (2016) juga menunjukkan adanya pengaruh profitabilitas terhadap pengungkapan lingkungan pada beberapa negara berkembang di dunia. Chang and Zhang (2010), Ohidoa, Omokhudu, and Oserogho (2016), Wahyuningrum and Budihardjo (2018) mengungkapkan bahwa tipe industri secara positif berpengaruh signifikan terhadap pengungkapan lingkungan. Walaupun beberapa penelitian lain menunjukkan hasil sebaliknya, diantaranya penelitian yang dilakukan oleh Khalid et al. (2017) dan . Berdasarkan dari latar belakang tersebut, penelitian ini menguji pengaruh antara ukuran perusahaan, profitabilitas, leverage, dan tipe industri terhadap pengungkapan lingkungan. Studi ini dilakukan pada perusahaan yang terdaftar di SGX selama periode tahun 2018.

Penelitian ini didasari oleh tiga teori yaitu teori legitimasi, teori stakeholder dan teori agensi. Hal ini disebabkan karena beberapa norma dan nilai sosial mempunyai batasan-batasan dan berpotensi memunculkan reaksi terhadap batasan tersebut, yang pada akhirnya mendorong kesadaran perusahaan tentang pentingnya analisis perilaku organisasi yang berdasar pada lingkungan dimana organisasi tersebut berdiri. Campbell (2003) menegaskan bahwa pengungkapan sosial dan lingkungan dapat digunakan untuk mempersempit atau bahkan menghilangkan kesenjangan antara tindakan perusahaan dan kepedulian sosial melalui teori legitimasi ini. 
Freeman (2010) mendefinisikan stakeholder sebagai pihak-pihak yang berkepentingan dalam perusahaan dan memiliki pengaruh yang sangat signifikan terhadap keberlangsungan operasi perusahaan. Deegan (2006) berpendapat bahwa manajemen organisasi diharapkan dapat melakukan kegiatan yang dianggap penting oleh stakeholders. Hal ini dipertegas bahwa seluruh stakeholders mempunyai hak untuk mendapatkan informasi terkait kelangsungan hidup organisasi. Teori ini menegaskan jika eksistensi perusahaan sangat memerlukan dukungan dari stakeholder dan tetap mempertimbangkan persetujuan stakeholder untuk aktivitas perusahaan.

Definisi teori keagenan (agency theory) menurut Jensen and Meckling (1976) adalah adanya hubungan antara principal dan agen yang didasari dengan adanya pemisahan kepemilikan dan pengendalian perusahaan, pemisahan penanggung risiko, pembuatan keputusan dan pengendalian fungsifungsi dalam perusahaan. Prinsipal disini adalah pemegang saham yang mendelegasikan pengambilan keputusan bisnis kepada manajer perusahaan sebagai perwakilan (agen) dari pemegang saham. Kondisi ini berpotensi menimbulkan konflik kepentingan (agency theory) akibat adanya asimetri informasi.

Ukuran perusahaan dinyatakan sebagai salah satu faktor yang mempengaruhi pengungkapan lingkungan. Semakin besar ukuran perusahan, maka akan semakin tinggi pula intensitas aktivitas usaha yang dilakukan. Diharapkan dengan adanya aktivitas operasional yang dilakukan perusahaan tersebut akan memberikan dampak yang baik terhadap lingkungan di sekitarnya. Burgwal and Vieira (2014) menyatakan bahwa ukuran perusahaan berpengaruh terhadap pengungkapan lingkungan. Berdasarkan pada teori legitimasi, perusahaan besar harus mempunyai respon yang lebih terkait dibandingkan dengan perusahaan lebih kecil dalam hal pengungkapan lingkungan. Hal ini karena kemungkinan dapat timbul dampak yang mengganggu ekosistem lingkungan dan masyarakat dari adanya aktivitas perusahaan. Diharapkan antara perusahaan dan masyarakat dapat terjalin hubungan yang baik jika kedua pihak melakukan tindakan yang saling menguntungkan. Hal ini menuntut perusahaan besar untuk melaporkan pengungkapan lingkungan sebagai tanggung jawab sosial terhadap masyarakat. Teori stakeholder juga menekankan bahwa perusahaan-perusahaan besar akan selalu mendapatkan pengawasan yang lebih dibandingkan dengan perusahaan kecil dan memiliki tanggungjawab lebih besar terkait aktivitas industri yang dapat berdampak pada lingkungan. Penelitian Welbeck et al. (2017) dan Wahyuningrum and Budihardjo (2018) menunjukkan bahwa ukuran perusahaan berpengaruh positif signifikan terhadap pengungkapan lingkungan.

$\mathrm{H}_{1}$ :Ukuran perusahaan berpengaruh secara positif signifikan terhadap pengungkapan lingkungan
Profitabilitas merupakan salah satu indikator penting yang dilakukan manajemen dalam mengelola aset perusahaan. Perusahaan yang menghasilkan laba tinggi otomatis akan menunjukkan kinerja keuangan perusahaan yang sehat (Yanto \& Muzzammil, 2016).

Chaklader and Gulati (2015) menyebutkan bahwa perusahaan dengan laba tinggi memiliki kewajiban untuk melakukan pengungkapan yang lebih luas sebagai wujud tanggung jawab kepada masyarakat. Perusahaan juga harus mampu meyakinkan masyarakat bahwa keuntungan besar yang diperoleh tidak mengurangi biaya lingkungan yang telah dianggarkan. Sebaliknya, perusahaan dengan laba rendah, akan kesulitan dalam hal pembiayaan lingkungan, sehingga perusahaan tersebut akan melakukan pengungkapan yang lebih terbatas. Hal ini sesuai dengan konsep teori stakeholder, dimana perusahaan harus mempertimbangkan hak-hak masyarakat luas, bukan hanya investor.

Gatimbu and Wabwire (2016) menggunakan return on equity (ROE) untuk mengukur profitabilitas perusahaan. ROE mengukur profitabilitas perusahaan dengan cara menghitung berapa banyak keuntungan yang diperoleh perusahaan dengan memanfaatkan modal yang bersumber dari para investor.

$\mathrm{H}_{2}$ : Profitabilitas berpengaruh positif signifikan terhadap pengungkapan lingkungan

Salah satu indikator yang dapat digunakan untuk mengukur seberapa besar tingkat ketergantungan perusahaan pada kreditur adalah leverage. Leverage juga dapat digunakan sebagai alat untuk melihat sejauh mana kemampuan perusahaan dalam membiayai aset perusahaan. Berdasarkan teori keagenan, semakin tinggi rasio leverage yang dimiliki perusahaan, akan menuntut perusahaan itu untuk mengungkapkan lebih banyak informasi (Jensen \& Meckling, 1976). Sebaliknya, perusahaan yang mempunyai tingkat leverage yang rendah dapat menggunakan modal yang mereka miliki untuk membiayai asetnya.

Terkait dengan teori stakeholder, leverage yang tinggi juga mengindikasikan adanya tanggung jawab perusahaan yang besar terhadap para krediturnya. Oleh karena itu, perusahaan akan lebih memilih menyelesaikan kewajibannya terlebih dahulu kepada kreditur dibanding melakukan pengungkapan lingkungan yang tidak diwajibkan oleh pemerintah. Choi, Lee, and Psaros (2013) menyatakan bahwa adanya penyusunan laporan sukarela (pengungkapan lingkungan salah satunya) oleh perusahaan akan menambah pengeluaran yang lebih besar otomatis akan menambah beban perusahaan.

$\mathrm{H}_{3}$ :Leverage berpengaruh positif signifikan terhadap pengungkapan lingkungan

Banyak penelitian terdahulu mengklasifikasi tipe industri dalam beberapa kelompok. Roberts (1992) membagi dua tipe industri yaitu high profile dan low profile dimana industri high profile mempunyai karakteristik antara lain tingkat resiko politik dan persaingan yang ketat serta tingginya tingkat 
sensitivitas terhadap lingkungan. Sebaliknya yang termasuk ke dalam industri low profile yaitu bidang layanan konsumen dan barang, komunikasi dan keuangan.

Sejalan dengan teori legitimasi, perusahaan berdampak kecil pada lingkungan akan lebih sedikit mengungkap informasi terkait pengelolaan lingkungan oleh perusahaan. Sebaliknya, perusahaan yang mempunyai dampak besar mendapat tuntutan dan tekanan untuk lebih banyak melakukan pengungkapan lingkungan terkait dengan aktivitas perusahaan di lingkungan tersebut. Otomatis, industri yang ada di dalam kategori high profile akan mendapatkan tekanan dari para pemangku kepentingan atau masyarakat tertentu terkait dengan teori stakeholder (Nugraha \& Juliarto, 2015). Hal ini akan mempengaruhi tingkat pengungkapan lingkungan perusahaan yang tergolong dalam high profile.

Perusahaan yang tergolong dalam sensitive industry cenderung menghasilkan polusi dan limbah lebih banyak dibandingkan dengan perusahaan nonsensitive industry. Sehingga, perusahaan yang tergolong dalam tipe sensitive industry berupaya untuk mendapatkan pengakuan dari masyarakat, salah satunya melalui pengungkapan lingkungan yang lebih luas, sebagai salah satu jaminan atas keberlanjutan aktivitasnya. Welbeck et al. (2017) dan Wahyuningrum and Budihardjo (2018) membuktikan adanya pengaruh secara positif dan signifikan antara tipe terhadap pengungkapan lingkungan.

\section{$\mathrm{H}_{4}$ : Tipe industri berpengaruh positif signifikan terhadap environmental disclosure}

\section{Metode Penelitian}

Populasi dalam penelitian ini adalah perusahaan yang terdaftar dalam Singapore Exchange (SGX) untuk tahun 2018 yang melaporkan annual report, sustainability report dan/atau mengungkapkan environmental disclosure pada website perusahaan. Teknik pengambilan sampel menggunakan teknik purposive sampling sesuai dengan kriteria seperti dalam termuat dalam Tabel 1. Total perusahaan yang terdaftar di SGX tahun 2018 adalah 212 dan 136 perusahaan dieliminasi karena tidak menerbitkan laporan keberlanjutan (sustainability report) dan atau annual report. Selanjutnya, 15 perusahaan merupakan data outlier dan harus dihapuskan dalam sampel penelitian ini sehingga didapat sampel sebanyak sebanyak 61 perusahaan. Penelitian ini menggunakan statistik deskriptif dari masing-masing variable dan analisis regresi linier berganda untuk pengujian hipotesis.

Variabel dependen yang digunakan adalah pengungkapan lingkungan yang diukur berdasarkan indikator pengungkapan lingkungan sesuai dengan Global Reporting Initiative (GRI) yaitu GRI Standards 2016. Empat variabel independen yang digunakan dalam penelitian ini adalah adalah profitabilitas dan leverage yang merupakan proxy dari kinerja keuangan serta karakteristik perusahaan yang menggunakan ukuran perusahaan dan tipe industri. Ukuran perusahaan diukur dengan melihat total aset yang dimiliki perusahaan, sedangkan tipe industri dibagi menjadi dua kelompok dengan variable dummy untuk pengukurannya yaitu industri yang tergabung dalam jenis sensitive dan non-sensitive. Adapun penjelasan definisi operasional untuk tiap variabel dapat dilihat pada Tabel 2.

Metode analisis yang digunakan terdiri dari statistik deskriptif, uji asumsi klasik, regresi linier berganda dan uji hipotesis. Persamaan regresi berganda ditunjukkan pada persamaan 1 .

$\mathrm{PL}=\beta 0+\beta 1 \mathrm{SIZE}+\beta 2 \mathrm{PROF}+\beta 3 \mathrm{LEV}+\beta 4 \mathrm{IND}+\varepsilon$

\section{Hasil dan Pembahasan \\ 3.1. Statistik Deskriptif}

Tabel 3 merupakan hasil analisis statistik deskriptif dari semua variabel. Hasil analisis statistik deskriptif menunjukkan bahwa sampel penelitian (n) sejumlah 61 perusahaan. Nilai rata-rata profitabilitas, leverage, ukuran perusahaan dan pengungkapan lingkungan secara berturut-turut yaitu 0,05, 0,38, 18,30 dan 8.69. Nilai rata-rata pengungkapan lingkungan, ukuran perusahaan dan tipe industri mempunyai nilai rata-rata lebih besar daripada nilai standar deviasinya. Hal ini dapat disimpulkan bahwa simpangan datanya relatif kecil dan menyebabkan sebaran data variabel-variabel tersebut bersifat homogen. Sebaliknya, nilai profitabilitas dan nilai leverage yang memiliki nilai rata-rata kurang dari standar deviasinya menunjukkan bahwa data variabel profitabilitas dan leverage bersifat heterogen karena simpangan datanya cukup besar.

Uji normalitas, uji multikolinieritas, uji heterokedastisitas dan uji autokorelasi dilakukan dalam penelitian ini sebagai prasyarat yang harus dipenuhi pada model regresi linear OLS (Uji Asumsi Klasik). Hasil uji normalitas menggunakan One Sample Kolmogorov-Smirnov menunjukkan nilai Kolmogorov-Smirnov (KS) sebesar 0.903 dengan nilai signifikansi sebesar $0.389>0.05$. Hal ini dapat disimpulkan bahwa data terdistribusi secara normal karena nilai signifikansinya lebih besar dari 0.05 . Uji multikolinieritas digunakan untuk menguji hubungan variabel bebas dalam suatu model regresi dimana variabel independen memiliki nilai tolerance $>0.10$ dan nilai VIF < 10. Berdasarkan dari hasil uji multikolinearitas tersebut, model regresi dalam penelitian ini tidak menunjukkan adanya gejala multikolinieritas. Uji heterokedastisitas dalam penelitian ini menggunakan uji Glejser dengan hasil semua variabel memiliki nilai signifikansi $>0.05$. Sehingga dapat disimpulkan tidak terdapat gejala heterokedastisitas pada model regresi ini. Uji autokorelasi dilakukan dengan menggunakan nilai Durbin-Watson test, dimana nilai DW menunjukkan angka 1.924 berarti tidak ditemukan gejala autokorelasi dalam model regresi ini.

Tabel 4 menampilkan hasil koefisien determinasi. Berdasarkan nilai Adjusted R2 sebesar 0.138 mengindikasikan bahwa sebesar $13.8 \%$ variasi 
pengungkapan lingkungan dijelaskan oleh variablevariabel dalam penelitian ini, sedangkan sebanyak 87.2\% sisanya dijelaskan oleh faktor-faktor lain di luar model penelitian ini. Hasil uji $F$ atau ANOVA menunjukkan F hitung sebesar 3.399 dan signifikansi $0.015<0.05$. Hal ini menunjukkan bahwa variable independen yaitu ukuran perusahaan, profitabilitas, leverage, dan tipe industri secara simultan berpengaruh terhadap environmental disclosure. Persamaan regresi berdasarkan regresi linier berganda penelitian ini yaitu:

$\mathrm{PL}=-18.372+1.145 \mathrm{SIZE}-1.138 \mathrm{PROF}+2.212 \mathrm{LEV}-$ $0.228 \mathrm{TYPE}$

\section{Ukuran perusahaan berpengaruh positif terhadap pengungkapan lingkungan}

Tabel 6 menyajikan hasil uji statistik menggunakan regresi linear berganda. Nilai signifikansi yang diperoleh adalah 0.007 mengindikasi bahwa hipotesis 1 dapat diterima. Ukuran perusahaan terbukti berpengaruh signifikan positif terhadap pengungkapan lingkungan. Total aset suatu perusahaan menunjukkan ukuran perusahaan tersebut. Semakin besar aset yang dipunyai perusahaan maka semakin besar pula ukuran perusahaan tersebut. Perusahaan dengan ukuran yang besar akan meningkatkan ketertarikan para investor untuk memberikan kepercayaannya dan meningkatkan nilai tambah pada perusahaan. Perusahaan besar lebih rentan untuk mengungkapkan informasi lingkungan daripada perusahaan kecil karena untuk menghindari hukuman dan mengurangi risiko regulasi (Burgwal \& Vieira, 2014). Hasil penelitian ini konsisten dengan teori legitimasi. Perusahaan besar lebih merespon environmental disclosure atau pengungkapan lingkungan sebagai tanggung jawab terhadap lingkungan dan masyarakat. Hubungan yang baik antara masyarakat dan perusahaan dapat terjalin jika kedua pihak melakukan tindakan yang saling menguntungkan dan tidak merugikan. Penelitian ini mendukung beberapa hasil penelitian sebelumnya yang diantaranya dilakukan oleh Welbeck et al. (2017) dan Khalid et al. (2017).

\section{Profitabilitas berpengaruh positif terhadap pengungkapan lingkungan}

Nilai signifikansi sebesar 0.542 dalam Tabel 6 menunjukkan bahwa profitabilitas terbukti tidak berpengaruh terhadap pengungkapan lingkungan. Profitabilitas merupakan kemampuan yang dimiliki oleh perusahaan untuk mendapatkan laba baik dari asset yang diniliki maupun dari pendapatan yang dilakukan oleh perusahaan. Dalam hal ini kemampuan perusahaan dalam mengelola kinerjanya akan berpengaruh pada laba yang dihasilkan. Tinggi rendahnya tingkat profitabilitas dalam penelitian ini tidak mempengaruhi pengungkapan lingkungan oleh perusahaan. Sebaliknya, teori legitimasi menyatakan bahwa masyarakat akan memberikan tekanan terhadap perusahaan untuk mengungkapkan pengungkapan lingkungan (Devie, Kamandhanu, Tarigan, \& Hatane, 2019). Tekanan yang diberikan masyarakat belum dapat memberikan dampak yang berarti bagi perusahaan. Tidak berpengaruhnya profitabilitas terhadap pengungkapan lingkungan dapat disebabkan karena perusahaan tidak sepenuhnya menggunakan laba yang diperoleh untuk meningkatkan pengungkapan lingkungan. Perusahaan akan bertendensi kuat untuk menggunakan laba yang diperoleh untuk mendanai kegiatan operasional perusahaan yang membutuhkan pembiayaan cukup tinggi. Sejalan dengan hasil penelitian Fortunella and Hadiprajitno (2015), Dibia and Onwuchekwa (2015), dan Welbeck et al. (2017), perusahaan terbukti belum menggunakan labanya untuk melakukan pengungkapan lingkungan sesuai standar yang ditetapkan.

\section{Leverage berpengaruh positif terhadap pengungkapan lingkungan}

Hasil uji hipotesis dalam Tabel 6 menunjukkan nilai signifikansi dari leverage terhadap pengungkapan lingkungan sebesar 0.149 yang lebih besar dari 0.05 . Hal ini membuktikan tidak adanya pengaruh antara leverage terhadap pengungkapan lingkungan. Tingkat leverage yang tinggi berdampak pada pengungkapan informasi lingkungan yang tinggi juga. Semakin banyak perusahaan mengandalkan pembiayaan utang, maka semakin besar kemungkinan untuk memberikan pengungkapan lingkungan yang lebih banyak (Elijido-Ten, 2004). Semakin tinggi tingkat leverage suatu perusahaan, pihak yang berkepentingan akan lebih melakukan pengawasan terhadap perusahaan tersebut diantaranya melalui pengungkapan lingkungan. Oleh sebab itu, dengan melakukan pengungkapan lingkungan perusahaan berusaha untuk menjaga kepercayaan dan sebagai tanggung jawab terhadap para stakeholder. Temuan ini sejalan dengan penelitian oleh Yanto and Muzzammil (2016).

\section{Tipe Industri berpengaruh positif terhadap pengungkapan lingkungan}

Berdasarkan Tabel 6, hipotesis keempat yang menguji pengaruh tipe industri terhadap pengungkapan lingkungan ditolak dengan nilai signifikansi nya 0.910 . Hal ini menujukkan bahwa tipe industri terbukti tidak berpengaruh terhadap pengungkapan lingkungan. Hasil penelitian ini tidak sejalan dengan teori stakeholder yang menyatakan bahwa perusahaan berkategori high profile akan lebih mendapatkan tekanan dibanding perusahaan low profile dari pemangku kepentingan masyarakat tertentu (Nugraha \& Juliarto, 2015). Tekanan sosial yang ada belum memberikan dampak yang berarti untuk membuat keputusan pada perusahaan industri di Singapura dalam mengungkapkan informasi lingkungannya. Berdasarkan perspektif teori stakeholder, tingkat yang diharapkan dalam praktik environmental disclosure pada dasarnya tergantung 
pada variasi kegiatan perusahaan (Khalid et al., 2017). Variasi kegiatan dalam penelitian ini menunjukkan perbedaan tipe industri dari sampel perusahaan. Tipe industri high profile mendapatkan hasil terbanyak daripada industri low profile. Tetapi, dalam penelitian ini industri high profile terbukti tidak berpengaruh terhadap pengungkapan lingkungan. Penelitian ini juga mendukung penelitian sebelumnya yang dilakukan oleh Stanton and Suttipun (2012) dan Khalid et al. (2017)

Tabel 1. Kriteria Pengambilan Sampel

\section{Kriteria}

Perusahaan industrial yang terdaftar di Singapore Exchange (SGX) tahun 2018

Perusahaan yang tidak melaporkan sustainability report dan/atau annual report

Perusahaan yang memiliki data outlier

Total perusahaan sampel

\section{Jumlah}

212

(136)

(15)

61

Tabel 2. Definisi Operasional Variabel Penelitian

\begin{tabular}{|c|c|c|}
\hline Variabel & Definisi & Pengukuran \\
\hline Pengungkapan Lingkungan & $\begin{array}{l}\text { Informasi yang diungkapkan } \\
\text { perusahaan terkait item-item } \\
\text { indikator lingkungan yang dilakukan oleh } \\
\text { perusahaan. }\end{array}$ & $\begin{array}{l}\text { Menggunakan checklist item terhadap informasi } \\
\text { terkait pengungkapan lingkungan sesuai dengan } \\
\text { item-item di GRI Standards } 2016 \text {. Skor } 1 \text { jika ada } \\
\text { informasi tentang pengungkapan lingkungan, dan } \\
\text { jika tidak ada diberi skor } 0 \text {. Skor yang diungkapkan } \\
\text { setiap unit analisis dijumlahkan kemudian dibagi } \\
\text { 30. }\end{array}$ \\
\hline Ukuran Perusahaan (Size) & Ukuran besar kecilnya suatu perusahaan & Ln (Total aset) \\
\hline Profitabilitas (Return on Equity-ROE) & $\begin{array}{l}\text { Rasio yang digunakan untuk mengukur } \\
\text { kemampuan suatu unit usaha dalam } \\
\text { menghasilkan keuntungan terkait dengan } \\
\text { ekuitasnya. }\end{array}$ & $\frac{\text { Laba Bersih }}{\text { Ekuitas }} \times 100 \%$ \\
\hline Leverage (Debt to Equity Ratio) & $\begin{array}{l}\text { Rasio untuk mengukur kemampuan suatu } \\
\text { unit usaha dalam membayar kewajiban/ } \\
\text { utang }\end{array}$ & $\frac{\text { Total Debt }}{\text { Total Aset }}$ \\
\hline Tipe Industri & $\begin{array}{l}\text { Berdasarkan tingkat sensitifitas industri } \\
\text { terhadap lingkungan }\end{array}$ & $\begin{array}{l}\text { Sensitive industry }=1 \\
\text { Non-sensisitive industry }=0\end{array}$ \\
\hline
\end{tabular}

Tabel 3. Hasil Statistik Deskriptif

\begin{tabular}{|c|c|c|c|c|c|}
\hline & $\mathbf{N}$ & Minimum & Maximum & Mean & Std. Deviation \\
\hline Profitabilitas & 61 & -2.117 & 1.145 & .05173 & .430769 \\
\hline Leverage & 61 & .001 & 2.565 & .38308 & .532611 \\
\hline Size & 61 & 14.731 & 24.029 & 18.30428 & 1.583874 \\
\hline Type & 61 & 0 & 1 & .82 & .388 \\
\hline Pengungkapan Lingkungan & 61 & 0 & 29 & 8.69 & 6.278 \\
\hline Valid N (listwise) & 61 & & & & \\
\hline
\end{tabular}

Tabel 4. Hasil Uji Koefisien determinasi

\begin{tabular}{|c|c|c|c|c|c|}
\hline Model & $\mathbf{R}$ & R Square & $\begin{array}{c}\text { Adjusted R } \\
\text { Square } \\
\end{array}$ & $\begin{array}{l}\text { Std. Error of the } \\
\text { Estimate }\end{array}$ & Durbin-Watson \\
\hline 1 &, $442^{a}$ & ,195 & 138 & 5,830 & 1,924 \\
\hline
\end{tabular}

a. Predictors: (Constant), SIZE, PROF, LEV, TYPE

b. Dependent Variable: $P L$

Tabel 5. Uji F

ANOVA $^{a}$

\begin{tabular}{|llrrrrr|}
\hline Model & & Sum of Squares & df & Mean Square & F & Sig. \\
\hline \multirow{4}{*}{1} & Regression & 462,003 & 4 & 115,501 & 3,399 &, $015^{\mathrm{b}}$ \\
& Residual & 1903,079 & 56 & 33,984 & & \\
& Total & 2365,082 & 60 & & \\
\hline
\end{tabular}

a. Dependent Variable: PL

b. Predictors: (Constant), SIZE, PROF, LEV, TYPE

Tabel 6. Simpulan Hasil Uji Hipotesis

\begin{tabular}{|c|c|c|c|c|}
\hline Hipotesis & Pernyataan & $\boldsymbol{\beta}$ & Sig. & Keputusan \\
\hline $\mathrm{H}_{1}$ & $\begin{array}{l}\text { Ukuran perusahaan berpengaruh secara positif signifikan terhadap pengungkapan } \\
\text { lingkungan }\end{array}$ & 1.145 & 0.007 & Diterima \\
\hline $\mathrm{H}_{2}$ & Profitabilitas berpengaruh positif signifikan terhadap pengungkapan lingkungan & -1.138 & 0.542 & Ditolak \\
\hline $\mathrm{H}_{2}$ & Leverage berpengaruh positif signifikan terhadap pengungkapan lingkungan & 2.212 & 0.149 & Ditolak \\
\hline $\mathrm{H}_{4}$ & Tipe industri berpengaruh positif signifikan terhadap pengungkapan lingkungan & -0.228 & 0.910 & Ditolak \\
\hline
\end{tabular}

\section{Kesimpulan}

Hasil penelitian ini menunjukkan bahwa hanya ukuran perusahaan yang terbukti berpengaruh secara positif signifikan terhadap pengungkapan lingkungan.
Sebaliknya, profitabilitas, leverage dan tipe industri terbukti tidak berpengaruh terhadap pengungkapan lingkungan oleh perusahaan. Penelitian ini hanya menggunakan data pengamatan perusahaan yang 
terdaftar di SGX selama 1 tahun pengamatan. Periode pengamatan yang lebih lama diharapkan dapat memperdalam hasil pengamatan. Selain itu, dapat pula ditambahkan variable lain dalam pengembangan penelitian seperti umur perusahaan, peran corporate governance maupun kinerja lingkungan yang sudah dilakukan oleh perusahaan yang diduga memiliki berpengaruh terhadap pengungkapan lingkungan.

\section{DAFTAR PUSTAKA}

Alotaibi, K. O., \& Hussainey, K. (2016). Determinants of CSR disclosure quantity and quality: Evidence from non-financial listed firms in Saudi Arabia. International Journal of Disclosure and Governance, 13(4), 364-393.

Burgwal, D. v. d., \& Vieira, R. J. O. (2014). Environmental disclosure determinants in Dutch listed companies. Revista Contabilidade \& Finanças, 25(64), 60-78.

Campbell, D. (2003). Intra-and intersectoral effects in environmental disclosures: evidence for legitimacy theory? Business Strategy and the Environment, 12(6), 357-371.

Chaklader, B., \& Gulati, P. A. (2015). A study of corporate environmental disclosure practices of companies doing business in India. Global Business Review, 16(2), 321-335.

Chang, K., \& Zhang, L. (2010). The effects of corporate ownership structure on environmental information disclosure-empirical evidence from unbalanced penal data in heavy-pollution industries in China. disclosure, 13(14).

Chen, Y.-C., Hung, M., \& Wang, Y. (2018). The effect of mandatory CSR disclosure on firm profitability and social externalities: Evidence from China. Journal of Accounting and Economics, 65(1), 169190.

Choi, B. B., Lee, D., \& Psaros, J. (2013). An analysis of Australian company carbon emission disclosures. Pacific Accounting Review.

D'Amico, E., Coluccia, D., Fontana, S., \& Solimene, S. (2016). Factors influencing corporate environmental disclosure. Business Strategy and the Environment, 25(3), 178-192.

Deegan, C. (2006). Legitimacy theory.

Devie, D., Kamandhanu, J., Tarigan, J., \& Hatane, S. E. (2019). Do environmental performance and disclosure bring financial outcome? Evidence from Indonesia. World Review of Science, Technology and Sustainable Development, 15(1), 66-86.

Dibia, N. O., \& Onwuchekwa, J. C. (2015). Determinants of environmental disclosures in Nigeria: A case study of oil and gas companies. International Journal of Finance and Accounting, 4(3), 145-152.

Elijido-Ten, E. (2004). Determinants of environmental disclosures in a developing country: an application of the stakeholder theory. Paper presented at the Fourth Asia Pacific Interdisciplinary Research in Accounting Conference.

Fortunella, A. P., \& Hadiprajitno, P. B. (2015). The Effects Of Corporate Governance Structure And Firm Characteristic Towards Environmental Disclosure. Fakultas Ekonomika dan Bisnis.

Freeman, R. E. (2010). Strategic management: A stakeholder approach: Cambridge university press.
Gatimbu, K. K., \& Wabwire, J. M. (2016). Effect of Corporate Environmental Disclosure on Financial Performance of Firms Listed at Nairobi Securities Exchange, Kenya.

Jackson, G., Bartosch, J., Avetisyan, E., Kinderman, D., \& Knudsen, J. S. (2020). Mandatory non-financial disclosure and its influence on CSR: An international comparison. Journal of Business Ethics, 162(2), 323-342.

Jensen, M. C., \& Meckling, W. H. (1976). Theory of the firm: Managerial behavior, agency costs and ownership structure. Journal of financial economics, 3(4), 305360.

Khalid, T. B., Kouhy, R., \& Hassan, A. (2017). The impact of corporate characteristics on social and environmental disclosure (CSED): The case of Jordan. journal of Accounting and Auditing: Research and Practice, 2017, 369352.

Khlif, H., Guidara, A., \& Souissi, M. (2015). Corporate social and environmental disclosure and corporate performance. Journal of Accounting in Emerging Economies.

Liu, X., \& Zhang, C. (2017). Corporate governance, social responsibility information disclosure, and enterprise value in China. Journal of Cleaner Production, 142, 1075-1084.

Mathuva, D. M., \& Kiweu, J. M. (2016). Cooperative social and environmental disclosure and financial performance of savings and credit cooperatives in Kenya. Advances in accounting, 35, 197-206.

Nugraha, D., \& Juliarto, A. (2015). Profitabilitas, Leverage, dan Kinerja Lingkungan Terhadap Environmental Disclosure (Studi Empiris Pada Perusahaan yang Terdaftar di BEI dan Menjadi Peserta PROPER Tahun 2011-2013). Diponegoro Journal of Accounting, 4(4), 1-15.

Ohidoa, T., Omokhudu, O. O., \& Oserogho, I. (2016). Determinants of environmental disclosure. International Journal of Advanced Academic Research/ Social \& Management Sciences, 2(8), 4958.

Plumlee, M., Brown, D., Hayes, R. M., \& Marshall, R. S. (2015). Voluntary environmental disclosure quality and firm value: Further evidence. Journal of Accounting and Public policy, 34(4), 336-361.

Roberts, R. W. (1992). Determinants of corporate social responsibility disclosure: An application of stakeholder theory. Accounting, organizations and society, 17(6), 595-612.

Stanton, P., \& Suttipun, M. (2012). Determinants of Environmental Disclosure in Thai Corporate Annual Reports. International Journal of Accounting and Financial Reporting, 2(1).

Wahyuningrum, I., \& Budihardjo, M. (2018). Relationship between Company Financial Performance, Characteristic and Environmental Disclosure of ASX Listed Companies. Paper presented at the E3S Web of Conferences.

Welbeck, E. E., Owusu, G. M. Y., Bekoe, R. A., \& Kusi, J. A. (2017). Determinants of environmental disclosures of listed firms in Ghana. International journal of corporate social responsibility, 2(1), 11.

Yanto, H., \& Muzzammil, B. (2016). A long way to implement environmental reporting in Indonesian mining companies. Available at SSRN 2908974. 